\title{
Slc20a2 is critical for maintaining a physiologic inorganic phosphate level in cerebrospinal fluid
}

\author{
Nina Jensen ${ }^{1,2}$ • Jacob Kwasi Autzen ${ }^{2}$ - Lene Pedersen ${ }^{1,2}$
}

Received: 22 November 2015 / Accepted: 29 November 2015 /Published online: 12 December 2015

(C) The Author(s) 2015. This article is published with open access at Springerlink.com

\begin{abstract}
Mutations in the SLC20A2-gene encoding the inorganic phosphate $(\mathrm{Pi})$ transporter PiT2 can explain approximately $40 \%$ of the familial cases of the rare neurodegenerative disorder primary familial brain calcification (Fahr's disease). The disease characteristic, cerebrovascular-associated calcifications, is also present in Slc20a2-knockout (KO) mice. Little is known about the specific role(s) of PiT2 in the brain. Recent in vitro studies, however, suggest a role in regulation of the [Pi] in cerebrospinal fluid (CSF). We here show that Slc20a2-KO mice indeed have a high CSF [Pi] in agreement with a role of PiT2 in Pi export from the CSF. The implications in relation to disease mechanism are discussed.
\end{abstract}

Keywords $S L C 20 A 2 \cdot$ Inorganic phosphate $\cdot$ Cerebrospinal fluid - Primary familial brain calcification · Fahr's disease . SLC20A1

\section{Introduction}

Primary familial brain calcification (PFBC), formerly Fahr's disease, is a rare autosomal dominantly inherited neurodegenerative disorder with neuropsychiatric and motor symptoms. It is characterized by calcifications in the basal ganglia and other brain regions. At least $40 \%$ of the cases of PFBC are linked to deleterious mutations in the gene SLC20A2, which encodes

Lene Pedersen

lp@mbg.au.dk

1 Department of Clinical Medicine, Aarhus University, Aarhus, Denmark

2 Department of Molecular Biology and Genetics, Aarhus University, C. F. Møllers Allé 3, Building 1130, 8000 Aarhus, Denmark the type III $\mathrm{Na}^{+}$-dependent inorganic phosphate $(\mathrm{NaPi})$ symporter PiT2 [1-3], and recently, also a de novo mutation in $S L C 2 O A 2$ was identified in a patient presenting with brain calcifications [4]. The mutations are predicted to result in lack of PiT2 protein or in PiT2 proteins, which are shown or predicted to be unable to transport Pi [1-17]. Both types of mutations have been suggested to result in haplo-insufficiency of Pi transport in affected cells [1]. Calcifications in PFBC have been found associated with the brain vasculature, from where they are likely to arise $[18,19]$. Slc20a2-knockout (KO) mice present with a similar calcification phenotype [20].

A certain Pi level in the body is essential due to its buffer function and role in basic cellular processes. Pi itself is, in addition, emerging as a specific signaling molecule in mammalian cells [21]. In humans, a Pi concentration in the blood (serum phosphate) between 0.8 and $1.5 \mathrm{mM}$ is considered within the normal range. Serum Pi levels above $1.5 \mathrm{mM}$ (hyperphosphatemia), which are prevalent in chronic kidney disease patients, are associated with peripheral vascular calcification [22]. In vitro studies show that exposure of vascular smooth muscle cells to hyperphosphatemic conditions leads to trans-differentiation to a mineralizing cell-type [22]. In vivo, both pericytes and vascular smooth muscle cells are suggested to play active roles in peripheral vascular calcification by their trans-differentiation to mineralizing cell-types [22, 23]. Interestingly, based on studies of vascular smooth muscle cells, a key step in the Pi-induced calcification process is deregulated expression of type III NaPi symporters, which besides SLC20A2 comprise the highly related SLC20A1 [24]. Individuals with PFBC do, however, not show elevated serum [Pi] [1, 5, 25], and the function and role of PiT2 in relation to PFBC are not known.

There is increasing evidence that cerebrospinal fluid (CSF) composition is important in brain development and in maintenance of the health of the adult brain [26]. Recent results 
suggest that during sleep, the CSF follows a para-arterial pathway into the brain's parenchyma via the so-called glymphatic system [27]. This process mixes CSF and interstitial fluid (ISF) and is suggested to lead to clearance of waste products from the brain $[26,27]$. In the CSF in mammals, the [Pi] is maintained at a lower level than in the blood [28-31]. Thus, it must be expected that the ISF [Pi] is also lower than blood [Pi]. In humans, measurements on the blood and CSF taken at the same time show approximately 0.4 -fold lower [Pi] in CSF [28-30]. It is not known how the CSF [Pi] is kept at a lower level than the blood [Pi].

The choroid plexus (ChP) localized at the lateral, the third, and the fourth ventricles produces most of the CSF, which has a high daily turnover rate [32]. In situ hybridization shows high expression of Slc20a2 in mouse ChP [33]. Recently, Guerreiro and coworkers addressed the Pi transport characteristics of isolated ChP from the spiny dogfish shark, Squalaus acanthias, which also maintains its CSF [Pi] lower than its blood [Pi] [34]. Their results suggest that $\mathrm{Pi}$ is actively removed from the CSF by PiT2. Thus, analysis of the transepithelial Pi flux of ChP from the spiny dogfish shark using an Ussing chamber, identified a $\mathrm{Na}^{+}$-dependent Pi flux from CSF to the blood. The Pi transport characteristics were in agreement with those of PiT2 [34], e.g., it showed lithiumdependent Pi transport [7]. Only two $\mathrm{Na}^{+}$-dependent $\mathrm{Pi}$ symporters, the type III NaPi symporters PiT2 and PiT1 (encoded by $S L C 20 A 1$ ), were found to be expressed in ChP from spiny dogfish sharks. PiT2 was predominantly localized to the $\mathrm{ChP}$ apical microvillar membranes, which faces the CSF, while PiT1 localized predominantly to the vascular endothelial cells. The localizations were confirmed on sections of rat lateral ChPs [34]. These results suggest that PiT2 plays a major role in maintaining the low $[\mathrm{Pi}]$ in the CSF by exporting Pi from the CSF to the blood. We hypothesized that if PiT2 is important in Pi export from the CSF, Slc20a2-KO mice should present with an increased CSF [Pi] compared to wild-type (WT) mice.

\section{Materials and methods}

The breeding pairs, C57BL/ $6 \mathrm{~N}^{\text {Tac }}-S l c 20 a 2^{\text {tmla(EUCOMM)Wtsi/ }}$ Ieg (EM:05549), were obtained from the European Mouse Mutant Archive, Germany; the strain has been described previously [20]. All mice were fed with the same standard diet ad libitum. The mice were anesthetized with an initial dose of medetomidine $(0.3 \mathrm{mg} / \mathrm{kg})$, midazolam $(4 \mathrm{mg} / \mathrm{kg})$, and butorphanol $(5 \mathrm{mg} / \mathrm{kg})$, and after 15-20 min, an additional dose was given to reach a surgical plane of anesthesia. When anesthetized, the mice were positioned in a stereotaxic frame, and CSF was drawn from the cisterna magna using a glass capillary. The mice were sacrificed, and the blood was immediately sampled by cardiac puncture. The [Pi] in CSF and serum was determined using a malachite green-based assay as described previously [35]. Data were analyzed by a Welch's $t$ test using R version 3.2.2 [36]. Mean values were considered different when $P<0.05$.

\section{Results}

To address whether Slc20a2-KO mice have an elevated [Pi] in the CSF, we measured the $[\mathrm{Pi}]$ in $\mathrm{CSF}$ and blood drawn from 3-week-old Slc20a2-KO mice and WT litter mates. In average, the WT mice showed a serum [Pi] of $4.79 \pm 0.65 \mathrm{mM}$ (standard deviation) and a CSF [Pi] of $0.90 \pm 0.25 \mathrm{mM}$ (Fig. 1). The average CSF $[\mathrm{Pi}] /$ serum [Pi] ratio was 0.19 (range 0.11-0.32) (Table 1). To our knowledge, the [Pi] of CSF of mice has not previously been published; for comparison, the corresponding ratio reported in 3-week-old rats is approximately 0.17 [31].

The average serum [Pi] of the Slc20a2-KO mice was $4.01 \pm 0.67 \mathrm{mM}$, which was 0.84 -fold lower than the average serum $[\mathrm{Pi}]$ in WT mice $(p<0.01)$ (Fig. 1). However, the average CSF [Pi] of the Slc20a2-KO mice was $2.19 \pm 0.41 \mathrm{mM}$, i.e., 2.4-fold higher than the average CSF [Pi] at $0.90 \mathrm{mM}$ of WT mice $(p<0.000001)$ (Fig. 1). Correspondingly, the average CSF $[\mathrm{Pi}] /$ serum [Pi] ratio of the Slc20a2-KO mice was 0.57 (range 0.41-0.99) (Table 1). Thus, Slc20a2-KO mice were unable to sustain their CSF [Pi] at the same low level as the WT mice.

\section{Discussion}

It is now well-established that deleterious mutations in the gene SLC20A2 are linked to PFBC [1-17], which is characterized by cerebrovascular-associated calcifications [18, 19]. A similar calcification phenotype is present in Slc20a2-KO mice [20]. The disease mechanism is unknown, but recent in vitro results [34] suggested a role of PiT2 in maintaining the low CSF [Pi] observed in healthy individuals. The here observed inability of Slc20a2-KO mice to sustain the same low CSF [Pi] as found in WT mice is in agreement with a role of PiT2 as an exporter of Pi from the CSF. The elevated CSF [Pi] likely also leads to an elevation of ISF [Pi]. With reference to hyperphosphatemia, we suggest an introduction of the term CSF hyperphosphate to describe Pi levels in the CSF above the highest concentration occurring in the non-pathologic situation.

To our knowledge, the CSF [Pi] in individual carriers of SLC20A2-associated PFBC has not been investigated, and it remains to be seen whether they also present with CSF hyperphosphate. The here presented new insight in the role of PiT2 in maintaining CSF normophosphate in mice, however, points at a potential mechanism, or contributing 
Fig. $1[\mathrm{Pi}]$ in serum and CSF from 3-week-old WT and Slc20a2KO mice. a CSF sampled from 11 WT ( 8 females, 3 males) and 10 KO ( 8 females, 2 males). b Serum sampled from 14 WT (10 females, 4 males) and $12 \mathrm{KO}$ (9 females, 3 males). KO compared to WT: CSF $[\mathrm{Pi}](p<0.000001)$ and serum $[\mathrm{Pi}]$ $(p<0.01)$ a

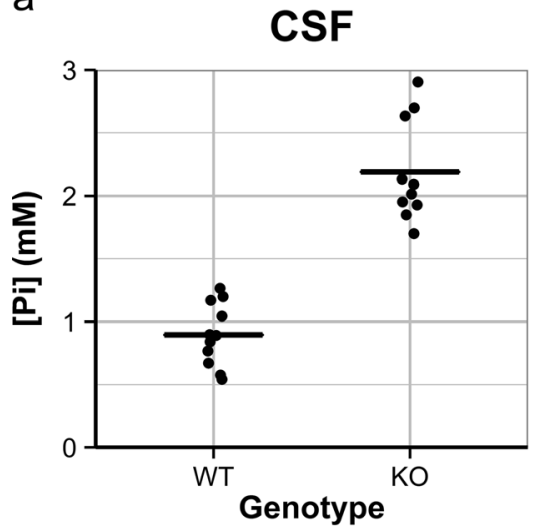

b mechanism, behind the cerebral vessel disease present in SLC20A2-associated PFBC and sporadic cases, i.e., CSF hyperphosphate. Specifically, pericytes/vascular smooth muscle cells in the brain might react in a similar manner to CSF
Table 1 [Pi] in serum and CSF from 3-week-old WT and Slc20a2-KO mice

\begin{tabular}{|c|c|c|c|c|}
\hline Genotype & Sex & {$[\mathrm{Pi}]^{\mathrm{a}}$ serum } & [Pi] CSF & {$[\mathrm{Pi}] \mathrm{CSF} /[\mathrm{Pi}]$ serum } \\
\hline WT & Female & 5.07 & 1.20 & 0.24 \\
\hline WT & Female & 5.69 & ND & - \\
\hline WT & Female & 5.56 & 1.04 & 0.19 \\
\hline WT & Female & 4.71 & 0.54 & 0.11 \\
\hline WT & Female & 3.48 & 0.84 & 0.24 \\
\hline WT & Female & 4.96 & 0.67 & 0.14 \\
\hline WT & Female & 4.91 & 0.77 & 0.16 \\
\hline WT & Female & 5.29 & ND & - \\
\hline WT & Female & 3.86 & 0.58 & 0.15 \\
\hline WT & Female & 4.87 & 0.89 & 0.18 \\
\hline WT & Male & 4.87 & 1.17 & 0.24 \\
\hline WT & Male & 3.98 & 1.26 & 0.32 \\
\hline WT & Male & 5.42 & 0.90 & 0.17 \\
\hline WT & Male & 4.45 & ND & - \\
\hline $\mathrm{KO}$ & Female & 4.63 & ND & - \\
\hline $\mathrm{KO}$ & Female & 4.25 & 1.93 & 0.45 \\
\hline $\mathrm{KO}$ & Female & 4.96 & ND & - \\
\hline $\mathrm{KO}$ & Female & 4.02 & 1.70 & 0.42 \\
\hline $\mathrm{KO}$ & Female & 4.74 & 1.95 & 0.41 \\
\hline $\mathrm{KO}$ & Female & 2.81 & 2.09 & 0.74 \\
\hline $\mathrm{KO}$ & Female & ND & 2.63 & - \\
\hline $\mathrm{KO}$ & Female & 4.01 & 2.13 & 0.53 \\
\hline $\mathrm{KO}$ & Female & 2.92 & 2.90 & 0.99 \\
\hline $\mathrm{KO}$ & Female & 3.75 & 1.85 & 0.49 \\
\hline $\mathrm{KO}$ & Male & 4.44 & 2.70 & 0.61 \\
\hline $\mathrm{KO}$ & Male & 4.01 & ND & - \\
\hline $\mathrm{KO}$ & Male & 3.54 & 2.01 & 0.57 \\
\hline \multicolumn{2}{|c|}{ Average for WT mice with CSF sample } & 4.70 & 0.90 & 0.19 \\
\hline \multicolumn{2}{|c|}{ Average for all WT mice } & 4.79 & - & - \\
\hline \multicolumn{2}{|c|}{ Average for KO mice with CSF sample } & 3.83 & 2.19 & 0.57 \\
\hline \multicolumn{2}{|c|}{ Average for all $\mathrm{KO}$ mice } & 4.01 & - & - \\
\hline
\end{tabular}

ND not done

${ }^{\mathrm{a}}[\mathrm{Pi}]$ in millimolar 
hyperphosphate, as the peripheral vascular cells are suggested to react to hyperphosphatemia [22, 23], i.e., by shifting phenotype and being actively involved in the calcification of the blood vessels. This hypothesis does not exclude that impaired PiT2 function in specific cell types in the brain outside the $\mathrm{ChP}$, e.g., in the pericytes/vascular smooth muscle cells, also directly contributes to the disease development. The presented results, however, provide the first insight into PiT2's function in normal brain physiology in an animal model presenting with a similar calcification phenotype as found in PFBC.

Recently, mutations in another gene encoding a protein associated with cellular Pi homeostasis, $X P R 1$, were also found associated with PFBC [37]. However, while $S L C 20 A 2$ encodes an importer of Pi into cells $[38,39]$, $X P R 1$ encodes a protein exporting Pi out of cells [40]. XPR1 proteins harboring damaging mutations associated with PFBC showed severely reduced membrane localization and/or impaired ability to export Pi out of cells to various degrees [37]. Interestingly, in situ hybridization shows expression of Xpr1 in mouse ChP [33]. Albeit the exact position of XPR1 in the ChP is not clear, it is tempting to speculate that it could be positioned in the basolateral membrane of the choroidal ependymal cells and be involved in Pi export from the cells to the blood side. Accordingly, impaired XPR1 transport could lead to increased intracellular Pi accumulation. Results on non-polarized mammalian cells in culture suggest that increased intracellular [Pi] might downregulate PiT2 expression in a cell-line specific manner [38, 41]. Thus, a potential increase in intracellular [Pi], due to impaired XPR1 function, might result in downregulation of PiT2-mediated apical Pi transport from the CSF into the ependymal cells. If the hypothesis is correct, damaging XPRI mutations could potentially also result in CSF hyperphosphate.

\section{Compliance with ethical standards}

Conflict of interest The authors declare that they have no conflict of interest.

Funding N. J. was sponsored by the Graduate School of Health at Aarhus University and the Danish Heart Association (15-R99-A5905-22947).

Ethical approval All applicable national guidelines for the care and use of mice were followed. All procedures performed in the study involving living animals were approved by the Danish Animal Experiments Inspectorate and performed in accordance with the approval.

This article does not contain any study with human participants performed by the authors.

Open Access This article is distributed under the terms of the Creative Commons Attribution 4.0 International License (http:// creativecommons.org/licenses/by/4.0/), which permits unrestricted use, distribution, and reproduction in any medium, provided you give appropriate credit to the original author(s) and the source, provide a link to the Creative Commons license, and indicate if changes were made.

\section{References}

1. Wang C, Li Y, Shi L, Ren J, Patti M, Wang T, de Oliveira JR, Sobrido MJ, Quintans B, Baquero M, Cui X, Zhang XY, Wang L, Xu H, Wang J, Yao J, Dai X, Liu J, Zhang L, Ma H, Gao Y, Ma X, Feng S, Liu M, Wang QK, Forster IC, Zhang X, Liu JY (2012) Mutations in SLC20A2 link familial idiopathic basal ganglia calcification with phosphate homeostasis. Nat Genet 44:254-256. doi: 10.1038/ng. 1077

2. Hsu SC, Sears RL, Lemos RR, Quintans B, Huang A, Spiteri E, Nevarez L, Mamah C, Zatz M, Pierce KD, Fullerton JM, Adair JC, Berner JE, Bower M, Brodaty H, Carmona O, Dobricic V, Fogel BL, Garcia-Estevez D, Goldman J, Goudreau JL, Hopfer S, Jankovic M, Jauma S, Jen JC, Kirdlarp S, Klepper J, Kostic V, Lang AE, Linglart A, Maisenbacher MK, Manyam BV, Mazzoni P, Miedzybrodzka Z, Mitarnun W, Mitchell PB, Mueller J, Novakovic I, Paucar M, Paulson H, Simpson SA, Svenningsson P, Tuite P, Vitek J, Wetchaphanphesat S, Williams C, Yang M, Schofield PR, de Oliveira JR, Sobrido MJ, Geschwind DH, Coppola G (2013) Mutations in SLC20A2 are a major cause of familial idiopathic basal ganglia calcification. Neurogenetics 14: 11-22. doi:10.1007/s10048-012-0349-2

3. Yamada M, Tanaka M, Takagi M, Kobayashi S, Taguchi Y, Takashima S, Tanaka K, Touge T, Hatsuta H, Murayama S, Hayashi Y, Kaneko M, Ishiura H, Mitsui J, Atsuta N, Sobue G, Shimozawa N, Inuzuka T, Tsuji S, Hozumi I (2014) Evaluation of SLC20A2 mutations that cause idiopathic basal ganglia calcification in Japan. Neurology 82:705-712. doi:10.1212/WNL.0000000000000143

4. Ferreira JB, Pimentel L, Keasey MP, Lemos RR, Santos LM, Oliveira MF, Santos S, Jensen N, Teixeira K, Pedersen L, Rocha CR, Dias da Silva MR, Oliveira JR (2014) First report of a de novo mutation at SLC20A2 in a patient with brain calcification. J Mol Neurosci 54:748-751. doi:10.1007/s12031-014-0357-9

5. Kasuga K, Konno T, Saito K, Ishihara A, Nishizawa M, Ikeuchi T (2014) A Japanese family with idiopathic basal ganglia calcification with novel SLC20A2 mutation presenting with late-onset hallucination and delusion. J Neurol 261:242-244. doi:10.1007/s00415013-7205-7

6. Bøttger P, Pedersen L (2011) Mapping of the minimal inorganic phosphate transporting unit of human PiT2 suggests a structure universal to PiT-related proteins from all kingdoms of life. BMC Biochem 12:21. doi:10.1186/1471-2091-12-21

7. Bøttger P, Pedersen L (2002) Two highly conserved glutamate residues critical for type III sodium-dependent phosphate transport revealed by uncoupling transport function from retroviral receptor function. J Biol Chem 277:42741-42747. doi:10.1074/jbc. M7096200

8. Zhang Y, Guo X, Wu A (2013) Association between a novel mutation in SLC20A2 and familial idiopathic basal ganglia calcification. PLoS One 8:e57060. doi:10.1371/journal.pone.0057060

9. Lemos RR, Oliveira MF, Oliveira JR (2013) Reporting a new mutation at the SLC20A2 gene in familial idiopathic basal ganglia calcification. Eur J Neurol 20:e43-e44. doi:10.1111/ene. 12044

10. Nicolas G, Charbonnier C, de Lemos RR, Richard AC, Guillin O, Wallon D, Legati A, Geschwind D, Coppola G, Frebourg T, Campion D, de Oliveira JR, Hannequin D (2015) Brain calcification process and phenotypes according to age and sex: lessons from SLC20A2, PDGFB, and PDGFRB mutation carriers. Am J Med Genet B Neuropsychiatr Genet 168:586-594. doi:10.1002/ajmg.b.32336

11. Nicolas G, Pottier C, Charbonnier C, Guyant-Marechal L, Le Ber I, Pariente J, Labauge P, Ayrignac X, Defebvre L, Maltete D, Martinaud O, Lefaucheur R, Guillin O, Wallon D, Chaumette B, Rondepierre P, Derache N, Fromager G, Schaeffer S, Krystkowiak P, Verny C, Jurici S, Sauvee M, Verin M, Lebouvier T, Rouaud O, 
Thauvin-Robinet C, Rousseau S, Rovelet-Lecrux A, Frebourg T, Campion D, Hannequin D (2013) Phenotypic spectrum of probable and genetically-confirmed idiopathic basal ganglia calcification. Brain 136:3395-3407. doi:10.1093/brain/awt255

12. Nicolas G, Pottier C, Maltete D, Coutant S, Rovelet-Lecrux A, Legallic S, Rousseau S, Vaschalde Y, Guyant-Marechal L, Augustin J, Martinaud O, Defebvre L, Krystkowiak P, Pariente J, Clanet M, Labauge P, Ayrignac X, Lefaucheur R, Le Ber I, Frebourg T, Hannequin D, Campion D (2013) Mutation of the PDGFRB gene as a cause of idiopathic basal ganglia calcification. Neurology 80:181-187. doi:10.1212/WNL.0b013e31827ccf34

13. Nicolas G, Richard AC, Pottier C, Verny C, Durif F, Roze E, Favrole P, Rudolf G, Anheim M, Tranchant C, Frebourg T, Campion D, Hannequin D (2014) Overall mutational spectrum of SLC20A2, PDGFB and PDGFRB in idiopathic basal ganglia calcification. Neurogenetics 15:215-216. doi:10.1007/s10048-0140404-2

14. Chen WJ, Yao XP, Zhang QJ, Ni W, He J, Li HF, Liu XY, Zhao GX, Murong SX, Wang N, Wu ZY (2013) Novel SLC20A2 mutations identified in southern Chinese patients with idiopathic basal ganglia calcification. Gene 529:159-162. doi:10.1016/j.gene.2013.07.071

15. Brighina L, Saracchi E, Ferri F, Gagliardi M, Tarantino P, Morzenti S, Musarra M, Patassini M, Annesi G, Ferrarese C (2014) Fahr's disease linked to a novel SLC20A2 gene mutation manifesting with dynamic aphasia. Neurodegener Dis 14:133-138. doi:10.1159/ 000365216

16. Gagliardi M, Morelli M, Annesi G, Nicoletti G, Perrotta P, Pustorino G, Iannello G, Tarantino P, Gambardella A, Quattrone A (2015) A new SLC20A2 mutation identified in southern Italy family with primary familial brain calcification. Gene 568:109111. doi:10.1016/j.gene.2015.05.005

17. Rubino E, Giorgio E, Gallone S, Pinessi L, Orsi L, Gentile S, Duca S, Brusco A (2014) Novel mutation of SLC20A2 in an Italian patient presenting with migraine. J Neurol 261:2019-2021. doi: 10.1007/s00415-014-7475-8

18. Miklossy J, Mackenzie IR, Dorovini-Zis K, Calne DB, Wszolek ZK, Klegeris A, McGeer PL (2005) Severe vascular disturbance in a case of familial brain calcinosis. Acta Neuropathol 109:643653. doi:10.1007/s00401-005-1007-7

19. Wider C, Dickson DW, Schweitzer KJ, Broderick DF, Wszolek ZK (2009) Familial idiopathic basal ganglia calcification: a challenging clinical-pathological correlation. J Neurol 256:839-842. doi:10. 1007/s00415-009-5025-6

20. Jensen N, Schrøder HD, Hejbøl EK, Füchtbauer EM, de Oliveira JRM, Pedersen L (2013) Loss of function of Slc20a2 associated with familial idiopathic basal ganglia calcification in humans causes brain calcifications in mice. J Mol Neurosci 51:994-999. doi:10. 1007/s12031-013-0085-6

21. Khoshniat S, Bourgine A, Julien M, Weiss P, Guicheux J, Beck L (2011) The emergence of phosphate as a specific signaling molecule in bone and other cell types in mammals. Cell Mol Life Sci 68: 205-218. doi:10.1007/s00018-010-0527-z

22. Shanahan CM, Crouthamel MH, Kapustin A, Giachelli CM (2011) Arterial calcification in chronic kidney disease: key roles for calcium and phosphate. Circ Res 109:697-711. doi:10.1161/ CIRCRESAHA.110.234914

23. Collett GD, Canfield AE (2005) Angiogenesis and pericytes in the initiation of ectopic calcification. Circ Res 96:930-938. doi:10. 1161/01.RES.0000163634.51301.0d

24. Crouthamel MH, Lau WL, Leaf EM, Chavkin NW, Wallingford MC, Peterson DF, Li X, Liu Y, Chin MT, Levi M, Giachelli CM (2013) Sodium-dependent phosphate cotransporters and phosphateinduced calcification of vascular smooth muscle cells: redundant roles for PiT-1 and PiT-2. Arterioscler Thromb Vasc Biol 33: 2625-2632. doi:10.1161/ATVBAHA.113.302249
25. Moskowitz MA, Winickoff RN, Heinz ER (1971) Familial calcification of the basal ganglions: a metabolic and genetic study. N Engl J Med 285:72-77. doi:10.1056/NEJM197107082850202

26. Lun MP, Monuki ES, Lehtinen MK (2015) Development and functions of the choroid plexus-cerebrospinal fluid system. Nat Rev Neurosci 16:445-457. doi:10.1038/nrn3921

27. Iliff JJ, Wang M, Liao Y, Plogg BA, Peng W, Gundersen GA, Benveniste H, Vates GE, Deane R, Goldman SA, Nagelhus EA, Nedergaard M (2012) A paravascular pathway facilitates CSF flow through the brain parenchyma and the clearance of interstitial solutes, including amyloid beta. Sci Transl Med 4:147ra111. doi:10. 1126/scitranslmed.3003748

28. Cantarow A (1932) Calcium studies VII The calcium and inorganic phosphorus content of cerebrospinal fluid and blood serum in chronic glomerulonephritis with uremia. Arch Intern Med 49: 981-993

29. Merritt HH, Bauer W (1931) The equilibrium between cerebrospinal fluid and blood plasma III. The distribution of calcium and phosphorus between cerebrospinal fluid and blood serum. J Biol Chem 90:215-232

30. Heipertz R, Eickhoff K, Karstens KH (1979) Magnesium and inorganic-phosphate content in CSF related to blood-brain-barrier function in neurological disease. J Neurol Sci 40:87-95. doi:10. 1016/0022-510x(79)90194-1

31. Sweeny JM, Seibert HE, Woda C, Schulkin J, Haramati A, Mulroney SE (1998) Evidence for induction of a phosphate appetite in juvenile rats. Am J Physiol Regul Integr Comp Physiol 275: R1358-R1365

32. Johanson CE, Duncan JA 3rd, Klinge PM, Brinker T, Stopa EG, Silverberg GD (2008) Multiplicity of cerebrospinal fluid functions: new challenges in health and disease. Cerebrospinal Fluid Res 5:10. doi:10.1186/1743-8454-5-10

33. Allen Mouse Brain Atlas (C) (2015) Allen Institute for Brain Science, http://mouse.brain-map.org/

34. Guerreiro PM, Bataille AM, Parker SL, Renfro JL (2014) Active removal of inorganic phosphate from cerebrospinal fluid by the choroid plexus. Am J Physiol Renal Physiol 306:F1275-F1284. doi:10.1152/ajprenal.00458.2013

35. Kongsfelt IB, Byskov K, Pedersen LE, Pedersen L (2014) High levels of the type III inorganic phosphate transporter PiT1 (SLC20A1) can confer faster cell adhesion. Exp Cell Res 326:5767. doi:10.1016/j.yexcr.2014.05.014

36. Team RC (2013) R: a language and environment for statistical computing

37. Legati A, Giovannini D, Nicolas G, Lopez-Sanchez U, Quintans B, Oliveira JR, Sears RL, Ramos EM, Spiteri E, Sobrido MJ, Carracedo A, Castro-Fernandez C, Cubizolle S, Fogel BL, Goizet C, Jen JC, Kirdlarp S, Lang AE, Miedzybrodzka Z, Mitarnun W, Paucar M, Paulson H, Pariente J, Richard AC, Salins NS, Simpson SA, Striano P, Svenningsson P, Tison F, Unni VK, Vanakker O, Wessels MW, Wetchaphanphesat S, Yang M, Boller F, Campion D, Hannequin D, Sitbon M, Geschwind DH, Battini JL, Coppola G (2015) Mutations in XPR1 cause primary familial brain calcification associated with altered phosphate export. Nat Genet 47:579581. doi:10.1038/ng.3289

38. Kavanaugh MP, Miller DG, Zhang W, Law W, Kozak SL, Kabat D, Miller AD (1994) Cell-surface receptors for gibbon ape leukemia virus and amphotropic murine retrovirus are inducible sodiumdependent phosphate symporters. Proc Natl Acad Sci U S A 91: 7071-7075. doi:10.1073/pnas.91.15.7071

39. Bøttger P, Hede SE, Grunnet M, Høyer B, Klaerke DA, Pedersen L (2006) Characterization of transport mechanisms and determinants critical for $\mathrm{Na}^{+}$-dependent Pi symport of the PiT family paralogs human PiT1 and PiT2. Am J Physiol Cell Physiol 291:C1377C1387. doi:10.1152/ajpcell.00015.2006 
40. Giovannini D, Touhami J, Charnet P, Sitbon M, Battini JL (2013) Inorganic phosphate export by the retrovirus receptor XPR1 in metazoans. Cell Rep 3:1866-1873. doi:10.1016/j.celrep.2013.05. 035
41. Chien ML, Foster JL, Douglas JL, Garcia JV (1997) The amphotropic murine leukemia virus receptor gene encodes a 71kilodalton protein that is induced by phosphate depletion. J Virol $71: 4564-4570$ 